\title{
Reading Matthew as a historical narrative
}

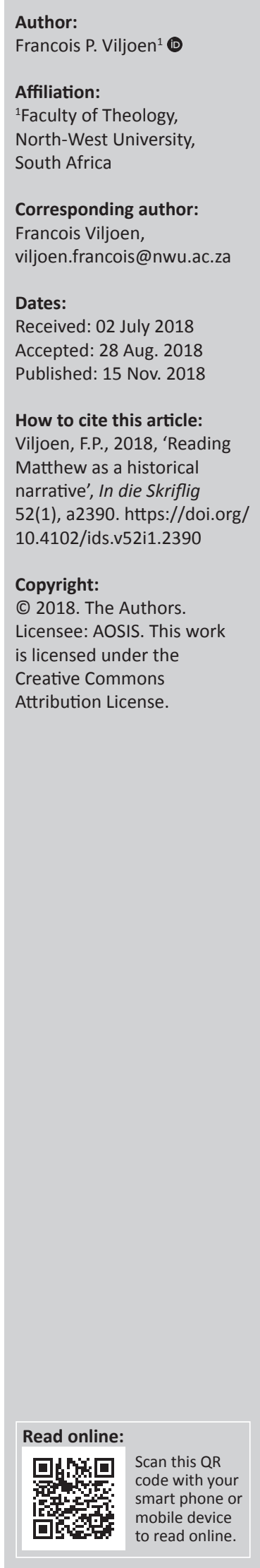

The grammatico-historical method of Bible interpretation is often used in traditional reformed hermeneutics and is usually defined as distinctive from historical and reader-response criticism. However, some aspects of grammatico-historical hermeneutics overlap with the latter two approaches. The argument in this article is that exegesis is a multi-faceted process which requires that various methods can be used to meet the requirements of the texts and the questions to be answered. As the Gospels are historical narratives, narrative criticism can provide a useful tool in interpreting these texts. This should not imply that the historical and theological character of these texts has to be invalidated, but rather that the integrity of these texts is appreciated and that they are read as authoritative for religious communities. The arguments in the article are illustrated with reference to the Matthean Gospel.

\section{Introduction}

The grammatico-historical method of Bible interpretation is often used in traditional reformed hermeneutics. This method strives to discover the author's original intended meaning in a biblical text. This method is usually said to be the opposite of the historical-critical approach which makes use of higher criticism. However, many aspects of grammatico-historical hermeneutics overlap with the historical-critical approach, as both methods attempt to determine what a passage meant when it was originally written. On the other hand, the grammatico-historical approach usually also steers away from reader-response criticism which focuses on how the text is perceived by the reader and not on the intention of the author. However, once again, some aspects in these two approaches overlap, as both methods are interested in what the text means for people today. One can therefore not simply place each of these approaches in isolated boxes, as some aspects of these approaches do overlap (cf. Hays 2013:3). It should be appreciated that a multi-faceted process is required to interpret a text. Depending on the objectives to be met and questions asked, various methods have to be used as they complement and reinforce one another (Brueggemann 1997:58; Du Toit 2009; Kennedy 2006:128; Perrin 1972:5-18). While a variety of methods are available, researchers should use methods that fit the requirements of the genre of the text, the objectives to be met and the questions to be answered. I substantiate this argument by using the Gospel of Matthew as an example.

While scholars debate the exact genre of the Gospels (cf. Burridge 1992) and what the intrinsic details of their genre may be, everyone has to concede that the Gospels are mostly narratives, focussing on the life of Jesus - stories that move from the beginning to conclusions. It is appropriate to typify the Gospels as both kerygmatic and as historical narratives. A kerygmatic narrative is 'meant to preach to the reader in narrative form and to elicit from the reader an act of Christian faith' (Karris 1985:8). Such a narrative reflects on the life and work of the Jesus of history.

However, not all scholars agree. It is usually argued that when reading a text as a narrative, a textimmanent approach should be followed with a non-referential view of the real historical world (Edwards 1997:6). On the other hand, the traditional historical-critical paradigm focuses on historical issues, while often disregarding the narrative integrity of the Gospels. It typically focuses on small details in the text and the reconstruction of what might lie behind the text (Carson \& Moo 2005:57). My approach is that the Gospels should be read as narratives without invalidating their historical and theological references.

My assumption is that insights from narrative criticism can provide useful tools for reading the Gospels. When a Gospel is read as a narrative text, it provides new insights about the nature and development of characters and events in the narrative (cf. Fokkelman 2000; Pennington 2012:160; Tolmie 1999:2-5). A narrative exegetical method is appropriate for a responsible reading of the Gospels as narratives. 
My aim with this article is to define such an approach. In doing so, I argue why the Gospels should be read as historical narratives and discuss different facets to be considered when reading it as such. A narrative is a complex structured entity where the meaning of different components is dependent on their relationship with the whole. Each Gospel is a narrative with characters, a storyteller with a point of view, an audience and a story with a plot. I illustrate my arguments with a number of references from the Matthean Gospel.

\section{Historical narratives}

A narrative approach usually differs from a historical approach to a text. Traditional historical-critical readings of the Gospels focus on the origin, socio-historical circumstances of it, their sources, forms, redaction, et cetera (Carson \& Moo 2005:54; Powell 1990:2). One of the most fundamental limitations of such a historical critical paradigm is that it often disregards the narrative integrity of the Gospels (Howell 1990:21). The narrative approach departs from such historical inquiry and examines the Gospels as literary units (Anderson 1994:26; Powell 1990:7). Narrative categories, such as character, plot, setting, discourse and how the story is told, form the focus of such study.

It is therefore often argued that when reading the Gospels as narratives, it should be read ahistorically with a textimmanent approach. Edwards (1997:6) argues that there should be no concern with the historical background. Only the world in the narrative, as constructed by the narrative, is relevant. Such a non-referential view of a narrative assumes that the narrative does not reflect the real world.

However, this literary paradigm in gospel studies should not invalidate historical and theological questions asked to the text (Hays 2013:17; Powell 1990:98). Although Culpepper (1984:472) admits that the narrative world of the Gospels is not identical to reflections of the world of Jesus or that of the evangelist, he states, 'Undoubtedly the narrative worlds of the Gospels are related in various ways ... to both the world of Jesus and the social world of the evangelist'. The reader must construct the real world from the narrative world.

When reading the Gospels as narratives, the historical and social contexts of the narrative world should therefore be taken into consideration, as these narratives are based on historical events. There is a referential aspect to the narratives of the Gospels, a subject with theological and soteriological implications with which the reader has to interact existentially so that the Gospel narratives can have their transformative effect (Howell 1990:36). The basis of this approach is that the biblical texts are historical, as they stem from a historical context. They are primarily referential, referring to entities beyond the texts themselves, and not purely 'literary'.

The situation of the narrator and narratees comes into play, as the Gospels are religious texts functioning in real religious communities that regarded these texts as authoritative for their faith and practice. The narrators wrote historical narratives, addressing religious communities that were confronted with real social and historical issues. The narrators refer to and reflect on the life of Jesus to address real issues with which the religious community was confronted. The Gospels should rather be read as occasional writings. The authors wrote to address specific concerns of real communities (cf. Foster 2004:3; Luz 2005:17; Powell 1990:88).

Sociological approaches (cf. Gager 1975; Theissen 1993), which reject radical ahistorical approaches, are more balanced. Significant relation to the world in which a text was produced and read, should not be neglected. Radical ahistorical approaches limit and can even skew the comprehension of a text. Stanton (1992:380) has remarks that if the horizons and expectations of the first readers of a text were ignored, 'interpretation would be like a picnic - a picnic to which ... we all bring our meanings'.

Although one should be cautious to make a historical reconstruction of the Gospel community based on the contents of the gospel (as this requires a considerable amount of interpretation), one can regard the Gospel narratives as 'inclusive'. Van Aarde (2011:49) remarks: “Two "worlds" are simultaneously included as a narrative entity.' From the text, a reader can recognise issues that were prevalent in the Gospel writer's community. The author retells the story of Jesus to address the contemporary needs of his audience. 'A text is not an isolated phenomenon, but functions in a communicative context and has a pragmatical function' (Weren 2014:9).

Different Gospel writers filled communicative needs by addressing particular situations and issues from the world in which they participated. The authors formed part of one or other early Christian community and wrote their Gospels with specific communities and some of their issues in mind (cf. Carter 2000:7; Klijn 1968:45; Love 2009:1). An author narrates the life of Jesus 'in illo tempore, but the text is deeply influenced by the situation of the community within which it originated and for which it was originally meant' (Weren 2014:251).

Hence, the goal of discerning the situation behind a text is not without problems. In a narrative, a narrative world is constructed within which narrative events occur (Howell 1990:14). This construction takes place as the story progresses and more information becomes available. The narrative world is constructed by selecting certain material to be told and a particular manner in which it is told. As the story continues, information is added or modified. The fallacy comes in when the starting point of exegesis is not the text as such, but some constructed or hypothetical historical situation behind the text. A 'referential fallacy' occurs when the narrative world is seen as a one-to-one relationship with the real world (Howell 1990:26). While the text and the society are undoubtedly related, the correlation is not precise. When reconstructing the social and religious setting of the text, the reader should keep in mind that this is based on the 
author's depiction of the world outside the text from his or her perspective. The reader does not have direct access to the real world as such. The text at hand contains an implied setting by an implied author for an implied audience.

The reconstruction of the historical setting can therefore never be absolute. For example, in an attempt to reconstruct the intended audience from the way it is depicted in the text, one should consider that the document could have been intended to promote core values of the audience that already existed, but could also have been intended to change their values (cf. Foster 2004:12). Nevertheless, the narrative world of the Gospels does reflect the real world, although not every detail of the real world is narrated, and it is narrated from a specific perspective to promote certain values.

While taking all these limitations into consideration, one has to acknowledge that responsible Bible reading cannot be ahistorical by absolutising the narrative text. The question is not whether one must choose between a historical or literary interpretation of the narrative text, but rather how the different methods contribute to the fuller understanding of the text, while recognising the limitations of each approach.

\section{Authors and audiences, narrators and narratees}

As narrative texts, the Gospels provide written commentaries to convey stories to intended audiences. An author uses a narrative to communicate with his or her readers. In a narrative approach, scholars distinguish, in addition to the real (actual) author and readers (audiences), also the implied authors and readers, narrators and narratees as indicated in Figure 1.

The implied author is the authorial presence the reader experiences in the narrative (Anderson 1994:27; Howell 1990:40; Tolmie 1999:13) - the image the real author creates of him- or herself. The implied author lives on after the flesh-and-blood author disappears. However, this implied author is not a character in the story. Likewise, the implied readers can be flesh-and-blood, but also hypothetical. The hypothetical readers can be internal or external to the text (Anderson 1994:31).

The narrator is the teller of the story - the one who speaks from the text itself. However, the narrator can also be a character in the story, becoming the voice of the implied author (Anderson 1994:46; Powell 1990:25). The narrators tell stories to narratees (Edwards 1997:5; Howell 1990:40; Powell 1990:27). However, the implied author and narrator, and the implied reader and narratee often become indistinguishable. This is usually the case with the Gospels.

Real author $\longrightarrow$ Implied author $\longrightarrow$ Narrator $\longrightarrow$ characters \& events $\longrightarrow$

narratee $\longrightarrow$ Implied reader $\longrightarrow$ real reader

FIGURE 1: Participants in narrative communication.
This concept of implied authors and readers, and of narrators and narratees, allows the reader to focus on the text itself and not on the assumed intent of the real author. The real author is usually a construct derived from the text itself. This construct is often utilised as a template in interpreting the text. Such an approach can easily lead to referential fallacy and hermeneutical circle argumentation, as the text is used to construct the author which, in his or her turn, is used to make sense of the text.

It is often assumed that the Matthean community is the implied audience (readers) of the first Gospel, with the disciples in the narrative representing them and the religious leaders (Pharisees and the teachers of the Law) as the rivals of the evangelist (Howell 1990:205). However, caution should be taken not to transfer a direct map of textual contents onto the reconstructed situation and origin of the text (Lategan 1982:76). Although the readers would tend to identify with the disciples as to answer to the call for discipleship, the implied audience has an advantage to this character group, as they have access not only to information communicated to the characters in the plotted story, but also the narrator's commentary. The implied audience (reader) is informed how to accept Jesus and how to interpret God's will from various character groups, because these characters are judged by the ideological point of view presented by the narrator.

\section{Characters and actants}

Characters are involved in the incidents that are narrated. Greimas (1983 [1966]:174-185, 192-212), an influential literary scientist, has defined the actants in narrative texts who fulfil actantial roles, for example the protagonist as the principle character or subject (such as Jesus in the Gospels), the supporters (helpers) who assist the protagonist (such as the disciples in some cases), the object(s) as the persons at whom the acts and values of the protagonist are directed (such as the disciples, crowds or marginalised figures in the Gospels), and the antagonists (opponents) as those who oppose the efforts of the protagonist (such as the Pharisees and scribes) ${ }^{1}$ (Van Aarde 2009:405). The plot develops as a result of the interrelation of such characters.

Characterisation is the techniques used to introduce the characters in the story. Characters are individuals or groups portrayed in the narrative. They participate in actions and in the plot. The portrait of a character is created by the combination of traits ascribed to a specific character (Anderson 1994:78; Powell 1990:51; Tolmie 1999:41). These traits can be presented by way of direct information from the narrator or by the conduct of speech of the character. By recognising these traits, the reader reaches a sensible conclusion of what kind of character appears in the story.

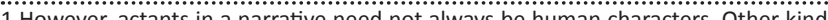
of anthromorphic beings, such as animals, can also function as actants. Even of anthromorphic beings, such as animals, can also function as actants. Even inanimate things such as a sword, a cross, darkness, et cetera can be considered as an actant. Due to the complexity of the system of all such characters, the discussion in this article is limited to human actants. 
However, such traits can be inconsistent throughout the story, creating confusion within the reader. To comprehend the character, it is therefore necessary to interpret different traits in relation to other traits of the character in the same story and where the same character is portrayed in different contexts (Edwards 1997:12; Prince 2003:73). If a character or set of characters respond in different situations as the story develops, the previous information is necessary to gain a fuller understanding of that character. Characters can change and develop with the unfolding of new incidents.

Relevant features to consider when identifying the traits of a character include the action taken by the character, the words or thoughts of this character, how this character is described, the response to this character by other characters in the story, and general interaction of this character with other characters. The individual status of a character is defined in terms of its relation with the main and other characters. Features of a character should be interpreted in terms of the specific incident as well as the context of this incident (Edwards 1997:13; Tolmie 1999:42).

A character-shaping incident is where the reader receives information to add a new trait to a character or to modify the already existing ones. When receiving such information, the reader combines the most recent information with previous material in the narrative of the character to form a picture of this character. When the background information is limited, the reader has to fill the gaps by hypothesis and judgements based on the narrative world of the story.

In the Gospel narratives, Jesus forms the main character. There are only a few incidents where he is not personally in the 'scenes'. However, all 'scenes' are related to Jesus. The whole plot of each Gospel centres on Jesus, while all characters and incidents are viewed in relation to him.

As main character, Jesus is the protagonist in the narratives. ${ }^{2}$ His teachings and actions form the focus of attention and the actions of other characters are directed towards him (Powell 1990:54; Weren 1994:12). The narrators side with Jesus without any reservations. Jesus is always portrayed in a positive light. Although other characters often react negatively to the character of Jesus, the narrators always portray Jesus as an authoritative and reliable figure. Jesus is the prototype of a pious person who perfectly does the will of God (Howell 1990:252). In their commentary on the narrated story, the narrators recommend Jesus' values to their readers and urge them to accept his values.

A wide range of features are used to characterise Jesus in the Gospels (Viljoen 2009:269-279). In the first Gospel, his character is introduced by way of his genealogy (Mt 1:1-17) and by the name Jesus given to him (Mt 1:21). In Matthew, he is significantly characterised by fulfilment citations 2.Theologically speaking, God the Father obviously also acts as protagonist as he sends his Son to save mankind. related to $\operatorname{him}^{3}$ (e.g. Mt 1:22-23; 2:15; 4:14-16; 8:17; 12:17-21; 13:35 and 21:4-5) and his honorific titles ${ }^{4}$ such

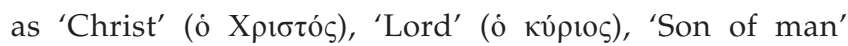

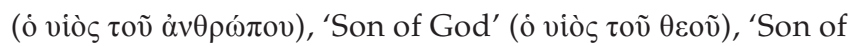
David' (ó viòs $\Delta \alpha v i \grave{\delta})$, 'Son of Abraham' (ó viòs A $\beta \rho \alpha \alpha \dot{\mu})$ ),

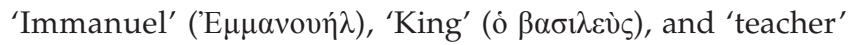

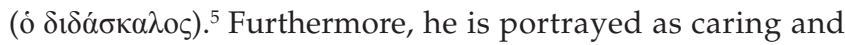
having compassion (e.g. Mt 14:14; ${ }^{6} 15: 32^{7}$ ), to mention but a few.

The character of Jesus serves as the standard against which the other figures are judged. Other characters are depicted based on the way they interact with Jesus (Edwards 1997:14). His statements, commands and criticism are authoritative and crucial for the evaluation of other characters. Therefore, the centrality of Jesus should always be recognised as the starting point when studying other characters in these texts. The other characters act as secondary characters in the narrative. Some characters react positively to Jesus and act as supporters, while others act negatively as opponents. Some characters remain neutral as spectators.

Jesus is almost always surrounded by supporting characters such as his disciples and other supplicants. They are portrayed positively, although in their humanness. As humans they sometimes disappoint, and in such cases act negatively. In this sense they become an inconsistent group of supporters of Jesus.

The disciples form the core group that responds positively towards Jesus. They respond positively to his calling by becoming his followers (Mt 4:18-22; 9:9), but at times also fail to support Jesus. Peter and the two sons of Zebedee did not keep watch with Jesus and fell asleep while Jesus was praying in anguish in the garden of Gethsemane ${ }^{8}$ (Mt 26:36-46). When Jesus was arrested, all his disciples deserted him and

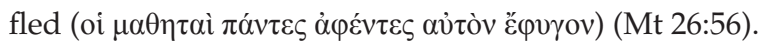

Peter is portrayed as spokesperson and leading figure among the disciples. He declares that Jesus is the Christ, the

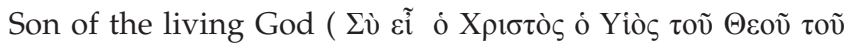
$\zeta \tilde{\omega} v \tau o \zeta)$ (Mt 16:18). His strengths and his weaknesses are described. The Matthean Jesus highlights his role when he pronounces, 'You are Peter' ( $\sigma \dot{~ \varepsilon i ̃ ~ П \varepsilon ́ \tau \rho o \varsigma), ~ a n ~ a l l e g o r i c a l ~}$ name, meaning 'rock' (Mt 16:18). He is introduced as Simon,

3 Scholars have recognised that the theme of fulfilment is a central motif in Matthew's Gospel (Viljoen 2007:301-324). While other New Testament writers Matthew's Gospel (Viljoen 2007:301-324). While other New Testament writers quoted a few obvious texts as fulfilled in Jesus, Matthew explored this motif
extensively (Davies \& Allison 2004:211; Versteeg 1992:23). France (1998:167) extensively (Davies \& Allison 2004:211; Versteeg 1992:
labels fulfilment as 'the special trademark' of this Gospel.

4.Many of the titles Matthew uses for Jesus, draw from the First Testament and Judaism. As he applies them to Jesus, he adds new layers of meaning.

5.In Matthew, references to Jesus as 'teacher' are usually derogative comments from those who would not recognise him as Lord.

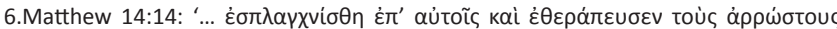

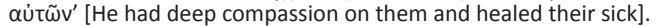

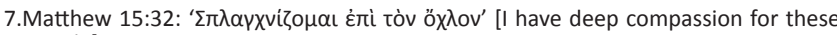
people].

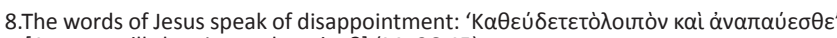
[Are you still sleeping and resting?] (Mt 26:45). 


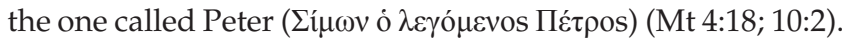
Elsewhere he is identified only as Peter (Mt 8:14; 14:28, 29; $15: 15 ; 16: 16)$. After Matthew $16: 18$, he is always addressed as Peter, except in Matthew 17:24-25. Yet, Peter's weaknesses are also portrayed. Jesus strongly rebukes him at Caesarea Philippi, telling him to 'Get behind me, Satan! You are a stumbling block to me; you do not have in mind the concerns of God, but merely human concerns' ('Y $\pi \alpha \gamma \varepsilon$ ỏ $\pi \dot{\sigma} \sigma \omega \mu \mathrm{ov}$,

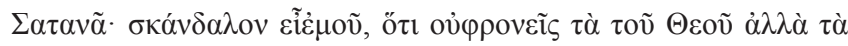
$\tau \tilde{\omega} v \dot{\alpha} v \theta \rho \omega ́ \pi \omega v)$ (Mt 16:13-28). Peter is also the one who repeatedly denies Jesus: 'I don't know the man!' (Oỏк oĩ $\delta \alpha$

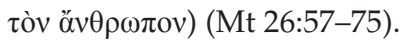

The character of Matthew, the tax collector, is significantly shaped by the narrative where he is called as disciple (Mt 9:9-13; Viljoen 2014a:218-224). By calling a tax collector and then dining with tax collectors and sinners, ${ }^{9}$ Jesus shows mercy to this marginalised figure by breaking social and religious conventions that prescribe that he should not associate with tax collectors (Carter 2000:219). Matthew obeys and follows Jesus, putting his trust in Jesus as he leaves behind everything he had (Senior 1998:104).

Several other characters are also portrayed as having positive attitudes towards Jesus. The wise men from the East came to worship Jesus ${ }^{10}$ and when they reached the house, they bowed and worshipped him. ${ }^{11}$

There are also individuals suffering the pangs of sickness, disease and death who seek healing from Jesus. Matthew tells a series of nine healing miracles stories (Mt 8-9;12 Viljoen 2014b:4). As supporting characters, these personages usually react positively to Jesus' teaching and ministry, and benefit accordingly. The readers can mirror themselves in these characters (Weren 1994:12). The Gospel writers create solidarity between the implied readers and Jesus, and the supporting characters.

Besides the supporting characters, there are also opponents of Jesus who act as antagonists such as the Jewish leaders, the Pharisees, Sadducees, scribes, chief priests, elders, Herodians, the Sanhedrin, Herod the King and Herod the tetrarch (Powell 1990:47). They are static characters who are wicked and hypocritical enemies of Jesus. They are, inter alia labelled as 'brood of vipers' (Mt 3:7; 12:34; 23:33), 'hypocrites' (Mt 6:2, 5, $16 ; 15: 7 ; 22: 18 ; 23: 13,15,23,25,27,29 ; 24: 51)$ and 'blind guides' (Mt 15:14; 23:16, 24, 34; Viljoen 2018:5-8). They do negative actions as they take counsel ( $\sigma \nu \mu \beta o v ́ \lambda$ เov) against Jesus

9.Tax collectors and sinners represent a disgraceful formulaic pair in the Synoptic Gospels. They were associated with shameful characters such as beggars, thieves and adulterers (cf. Mt 5:46; Lk 3:12-13; 5:29-30; 7:34, etc.; Malina \& Rohrbaugh 2003:415-416; Overman 1996:126).

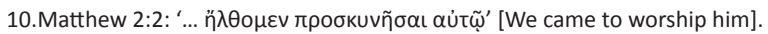

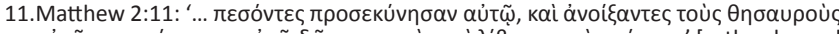

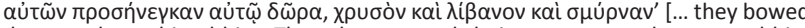
down and worshiped him. Then they opened their treasures and presented him with gifts of gold, frankincense and myrrh].

12.The nine healings are that of the leper, the centurion's servant, Peter's mother in law, the Gaderene demoniacs, the paralysed man, the ruler's daughter, the woman with blood flow, the blind men and the dumb man.
(Mt 12:14-15; 22:15; 26:3-4; 27:1, 7; 28:12) and are tempting

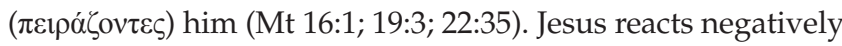
towards them. The reader is urged to also regard these antagonists as negative characters. These opponents form a prominent part of the outsider group. While the conflict between Jesus and the religious leaders is central throughout Matthew's plot, the conflict intensifies significantly in the final discourse of Matthew 23-25. Kingsbury (1995:169) regards the characters of the religious leaders as even more central to Matthew's plot than the disciples, as this conflict forms the focus of the plot.

The Gospels have a variegated view of the outsider group. One part consists of the opponents (adversaries) who are the scribes, Pharisees and Jewish religious leaders. As mentioned above, they are usually portrayed as the opponents of Jesus. The other part consists of a fluctuating group, the crowds and the Gentiles - characters who are in need of help. The author of Matthew, for example uses the word $\lambda \alpha$ ó $\varsigma$ [people] in its ordinary sense to refer to a social and political entity of the land of Israel, but also as people who need salvation: 'you are to give Him the name Jesus, because he will save his people (

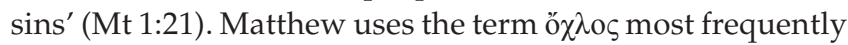
to refer to the people or crowds who gathered around Jesus. For the most part, the crowds are depicted as friendly and good-willed spectators, ${ }^{13}$ but are easily misled by Jewish leaders. The chief priests and the elders persuade the crowds ( $\tau$ ov̀ $\varsigma$ ö $\chi \lambda \mathrm{ov \varsigma}$ ) to ask for Jesus' death and Barabbas' release (Mt 27:20; cf. Saldarini 1994:27-43).

Besides these static characters, there are also dynamic characters (Anderson 1994:81). While static characters remain the same and do not change in any event, dynamic characters exhibit complexity and development along the plot line. A clear example of such a character is Jude who was one of the 12 disciples, but later betrayed Jesus (Mt 26:47-50).

The nature of each group is revealed in its interaction with Jesus (Anderson 1994:75). Each of these groups functions as a vehicle of ideological viewpoints. The implied reader is guided to share the ideological viewpoint of Jesus, instead of that of his antagonists, for example 'He taught them as one

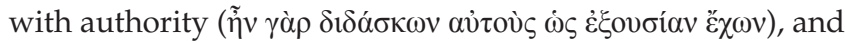
not as one of their teachers of the law' (Mt 7:29) and 'No one could say a word in reply, and from that day on no one dared to ask him any more questions' (Mt 22:46).

\section{Commentary and point of view}

A successful narrative is not merely a collection of loose standing events or literary units that can be read in an atomistic manner. It is a story with integrity, constructed in such a way that it influences the reader (Howell 1990:14). Each event has to be read as part of the whole of the narrative

13.While the crowds are not followers of Jesus in the strict sense of the word, they are at least potential followers. They are, for example the ones who are astonished at the words of Jesus in the Sermon on the Mount (Mt 7:2829). 
and its message. As mentioned above, Gospels are kerygmatic in nature. Gospel narratives reveal traces of Haggadah where the historical narrative finds its primary purpose in the conveyance of theological truth (Hagner 1993:25). When reading the Gospels as narratives, the aim is therefore to establish how the readers are informed, guided and influenced by the stories that are being told. This implies that the authors hold specific narrative points of view through which their stories are communicated (Powell 1990:24; Prince 2003:73).

A narrator can communicate with direct or explicit commentary (Anderson 1994:48). Several techniques can be used to provide direct or indirect commentary. It can consist of providing facts, moulding beliefs, relating events with established norms, highlighting the significance of events, generalising the significance of the work in general, manipulating mood or commenting on the text itself, et cetera (Howell 1990:180).

The point of view defines the perspective from which the narrative is presented (Anderson 1994:53; Howell 1990:37). The narrator (implied author) and the characters may have various points of view. Points of view can be in terms of ideology, time, geographical location, psychology, et cetera. It also designates the system of values and beliefs that are operative in the narrative world (Howell 1990:56; Tolmie 1999:22). Judgement of good or bad and right or wrong comes into play.

The same story may be told in different ways by different witnesses without intrinsically becoming different stories (Howell 1990:37). Aspecific point of view governs the selective process and the manner in which it is presented. The point of view reveals the interpretation of the narrator of the narrative world and what he or she regards as important and significant for the implied reader. ${ }^{14}$ When writing a Gospel, the evangelist writes within his interpretive community, and when the text is read, it is done within a new interpretive community (Howell 1990:46).

In the Gospels, the narrator's point of view is ideologically aligned with the character of Jesus. As mentioned before, Jesus is the protagonist and consistently the reliable character. In Matthew the reliability of Jesus is confirmed with several techniques such as titles used for Jesus Christ (Mt 1:1, 16, 18; 11:2; 16:16; etc.), ${ }^{15}$ 'Son of David' (Mt 1:1; 9:27; 12:23;15:22; 20:30, 31), ${ }^{16}$ 'Son of Abraham' (Mt 1:1), ${ }^{17}$

\footnotetext{
14.John, for example wrote:
}

Jesus performed many other signs in the presence of his disciples, which are not recorded in this book. But these are written that you may believe that Jesus is the Messiah, the Son of God, and that by believing you may have life in his name. (Jn 20:30-31)

15.It seems that Matthew chose this messianic title to explain his understanding of Jesus. Matthew's teaching of Jesus is rooted in Israel's messianic expectations, history and scriptures.

16.The expectation of the Davidic messianic king was widespread in Judaism and frequently used in rabbinic texts (Luz 2005:86). The title 'Son of David' occurs more frequently in Matthew's Gospel than in the rest of the New Testament (France 1998:284; Turner 2008:33). Matthew argues that Jesus is the expected Son of David, Israel's Messiah who was meant to be the Lord of the world.

17. Matthew stresses Jesus' Abrahamic lineage not only to show his Jewish roots, but also as the one in whom God's promises made to Abraham culminates (Turner 2008:33)
'Immanuel' (Mt 1:23), ${ }^{18}$ King (Mt 2:2; 27:11), ${ }^{19}$ 'Lord, ${ }^{20 \prime}$ 'Son of Man', ${ }^{21}$ and 'Son of God'22), his genealogy (Mt 1:1-17), ${ }^{23}$ angelic appearances (Mt 1:20-21; 2:13, 19; 28:2-7), fulfilment citations (Mt 1:22-23; 2:15; 2:17-18; 4:14-16; 8:17; 12:17-21; 13:35; 21:4-5; 27:9-10), ${ }^{24}$ dreams (e.g. Mt 1:20-24; 2:12, 13, 19-21, 22; 27:19), ${ }^{25}$ the guiding star (Mt 2:2, 9), ${ }^{26}$ the voice from heaven at Jesus' baptism (Mt 3:17) and on the Mount of transfiguration (Mt 17:5), ${ }^{27}$ and the recognition of Jesus by the disciples (e.g. Mt 16:16) and crowds (e.g. Mt 7:28-29).

The implied reader is guided to adopt Jesus's perspective. Story characters are structured according to particular values and readers are invited into this narrative world. The narrative does not merely tell the past story of Jesus' life. The narrator interprets incidents to establish sense for the implied readers. In this regard, Beardslee (1970:21) remarks 'one characteristic of the gospel form is ... its combination of two distinctive functions of religious narrative: the re-enactment of the past and the leading into the future'.

\section{Making sense of a narrative}

When reading the text as narrative, one should recognise that there are gaps in the story (Anderson 1994:33;

18. While Paul and John talk of the presence of the Holy Spirit as the means of God's continuing presence among his people, Matthew denotes this position to Jesus. He is the new and definitive form in which God is present with his people.

19.In Matthew 2:2, the author introduces Herod as the king (of Judea) and then immediately and ironically subverts his position by characterising Jesus, the newborn king of the Jews, who is worthy to be worshipped. Matthew poses two opposing levels of reality. On the surface level, Herod apparently is the king (over Judea), but on the deeper level of true reality, Jesus is the king of the Jews (Weaver 1996:182).

20.Matthew made abundant use of the word 'Kúplos'. He uses the word 80 times in comparison to 18 times in Mark and 103 times in Luke (Rigaux 1968:196). Matthew chose the term Lord with its overtones of power and authority demanding opponents address him, they never use the term Lord, but rather teacher, and then almost in a derogatory way.

21.The title Son of Man is related to the earthly condition of Jesus as the One that has to suffer and die, but also to his future vindication and glory. The Son of Man is the one who is homeless, rejected, blasphemed, the one who is handed over and killed. Yet, he is also the One with power over sins, who is risen, who is exalted and who comes in judgement (Luz 2005:110).

22.Some scholars argue ó viòৎ toũ $\theta \varepsilon$ oũ' is the pre-eminent title of Jesus in Matthew (Kingsbury 1976:591; Senior 1998:54). With biblical texts such as Psalm 2:7 and 89:27 as background, Matthew presents Jesus as the virginally conceived Son who uniquely signifies the presence of God with his people (Mt 1:23).

23.It is clear that the genealogy as introduction to the Gospel from the start identifies Jesus, the Son of David, as the Messiah who fulfils the plan of God.

24.Fulfilment quotations form some of the most frequent forms of commentary in Matthew. The narrator tells the narratee that what has happened, occurred to fulfil a prophesy. While other New Testament writers quoted a few obvious texts as fulfilled in Jesus, Matthew explored this motif extensively (Davies \& Allison 2004:211: Versteeg 1992:23). France (1998:167) labels fulfilment as 'the special trademark' of this Gospel.

25.Of all the New Testament writers, Matthew especially deals with revelation through dreams. The rest of the New Testament has few dreams or visions: Pau has a vision of a man of Macedon (Ac 16:9), Cornelius saw the angel of the Lord (Ac 10:1-8), Peter heard a voice with a vision (Ac 10:9-20) and Paul received encouragement from the angel of the Lord (AC 18:9; 23:11; 27:23). Scholar delineate dream reports according to form-critical elements: situation provided by the narrative, an introduction to the dream report, a theophany, a dream reference, a recipient, mentioning of the place, the auditory address formula, message, termination of the dream and the fulfilment of the command (Gnuse 1990:107).

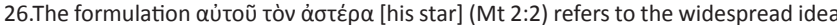
that each person had a star: important and rich people had bright stars, the stars of the others were insignificant. According to then popular astrology such a sta the others were insignicant. According to then popular astrology, such a sta appeared at birth and was extinguished at death (Luz 1990:135). Herod thus had much reason to be upset by the magi's report (Mt 2:3). An astrological signal of another ruler obviously indicated his own downfall. In those days celestial signs were commonly interpreted as signalling the death of one ruler and the consequent
rise of another (Malina \& Rohrbach 2003:32).

27.The modes of revelation in the Old Testament varied in external phenomena such 7.The modes of revelation in the Old Testament varied in external phenomena such
as visions, voices and dreams. Matthew apparently links up with such Old Testament forms of revelation and then transcends to the revelation in Jesus. 
Edwards 1997:7). Not every detail of the characters, actions or situations is told. The reader should fill the gaps by supplying what the texts omit or leave unsaid. The reader looks for connections and links between the gaps to create a coherent interpretation. Gaps can be filled by the reader's memory, expectations or the building up of associations that serve as contexts in reading through the text. It would have been easier for the first readers to fill these gaps, as they shared many of the social and cultural experiences and knew many of the events that are told. Within a different social and cultural situation and after many years have passed, the current readers would find it more difficult to fill these gaps. The risk is therefore that these gaps are filled by readers in different ways, leading towards different interpretations of the story. Furthermore, readers have different values, and cultural and historical contexts which result in differing responses to the narrative. Readers can unduly impose material upon the narrative world that is not presented in the narrative and which does not form part of the narrative world. It is therefore important that the narrative world must first be carefully defined before material external to the narrative can be brought in to form part of the interpretation of the narrative. Such material external to the text should obviously be introduced with careful discernment.

The Gospels are mostly compositions of sequences of short incidents, short actions and speeches. The Sermon on the Mount serves as example. Although it is known as the Sermon on the Mount, many scholars rather view Matthew 5-7 as a series of mashal-style statements and speeches grouped together by Matthew (cf. Domeris 1990:67). Suspense is created when it seems that statements even contradict one another as in Matthew 7:1-2 ('Do not judge, or you will too be judged ...') when compared with Matthew 7:6 ('Do not give dogs what is sacred; do not throw your pearls to pigs ...'). The reader is led to think beyond the text. Often little information is provided of circumstances surrounding these statements of incidents or of the characters in the story. The active role of the reader to make sense through interpretation should be recognised. Although the narrator guides the reader to make sense of these sequences, the reader needs to make sense based on own thinking and knowledge.

The mentioning of the names of the four women in the genealogy of Jesus (Rahab, Tamar, Ruth and indirectly Batsheba) (Mt 1:1-17), also constitute narratological gaps. Matthew does not provide an explanation of this unusual inclusion of women in this family tree. This compels the reader to think beyond the text to make sense of it. Another example is where men bring the paralytic to Jesus to be healed. Jesus saw their faith (Mt 9:2) which leads the reader to asking how faith can be visible. In Matthew 26:68 the reader is not told that Jesus is blindfolded, but has to assume this from the challenge posed to Jesus to identify those who beat him prophetically.

When filling these gaps, one must consider the role of the reader of hearing in making sense of the text. Scholars differ on such role. On the one extreme, scholars would say that readers merely have to find the meaning in the text. The text guides the reader to find such meaning. At the opposite extreme are those who argue that the reader creates meaning (Anderson 1994:31). Reader-response criticism takes such an approach. This school of literary theory focuses on the readers and their experience of a literary work.

A more balanced approach would be to argue what a text does to a reader, and what a reader does to the text. What happens when we read? When reading, the text supplies the reader with new information that develops knowledge and skills. On the other hand, the reader brings certain competencies, foreknowledge and information to the text in the process of making sense of it.

While having a high regard for the biblical text, one therefore has to recognise the influence of how a text is read. Each reader comes with presuppositions and reads within a social community. A reader reads in terms of the learned social, linguistic and literary conventions of an interpretative community (Anderson 1994:33).

Howell (1990:38) explains the role of the reader of a narrative in the discovery and production of textual meaning. He argues that the meaning of a text has an 'artistic' and 'aesthetic' dimension. The artistic refers to the text created by the author and the aesthetic to the reader's appreciation of the text (Howell 1990:40). However, one should be aware of the 'receptor's fallacy' where the reader almost becomes the sole arbiter or creator of the meaning of a text. The text forms the basis for the anticipated reaction of the reader. It contains the limit of the range of possible meanings and interpretations (Howell 1990:41).

Communication is not completed until the message of a text has reached its destination, that is, until it is comprehended and appropriated by the reader (Howell 1990:38). Meaning is produced in the interaction between author, text and reader. The reader is an active participant in this activity, as gaps in the story are being filled by him or her.

Narratives are valuable not only for the information that can be extracted from them, but also for the effect they have on the readers and the way they achieve these effects (Howell 1990:25). This communication involves a series of relationships between the author (sender), the text (message) and the reader or hearer (receiver) as presented in Figure 2.

The sender and receiver are connected with a message (communication channel) through which information flows. The message comes in the form of a code. The sender encodes the message and the reader has to decode it. When the receiver does not share precisely the same codes as the
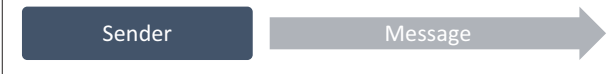

Receiver

FIGURE 2: Communication model. 
sender, he or she will be unable to fully decode the message which obviously leads towards a distortion of the message (Anderson 1994:35).

The influence of context should also be considered in the communication process. Communication takes place within a context and refers directly or indirectly to it (Anderson 1994:35). Narratives create narrative worlds that are related, although not identical to the real world. The narrative contains a selection from the actual world and is represented from a particular perspective.

\section{A story with a plot}

It should be considered that a story is developed in the form of a plot. Genette (1980) defines and describes the important difference between a 'story' and a 'plot' in Discours du récit. The 'story' (histoire) refers to the chronological sequence of events, and 'plot' to the way these events are presented in the narrative. When the events selected from the lives of people of certain times and places are combined into a series in relation to one another, a plot develops and the story becomes a narrative discourse (récit). The author delivers information to the audience with a series of events and in such a way creates a plot (Prince 2003:73; Tolmie 1999:63). The narrative discourse (récit) is directly available to the reader, while the story (histoire) should be abstracted from the narrative discourse. The narrator guides the reader through the narrated world. The narrator's voice is constantly heard as he or she incorporates his or her commentary into the narrative. He or she determines what is told and how it is told.

Events should therefore be interpreted in correlative terms and not merely episodic. Through the discernment of causal links, the logic of the narrative is revealed (Powell 1992:189; Tolmie 1999:64). Plot involves the temporal arrangements of the episodes of a story to form a narrative as a whole (Edwards 1985:9). The plot provides description of connections between the events with paradigmatic guidance (Powell 1992:188). It is the organising principle that provides different events with logic, causal relations and meaning (Matera 1987:240). It provides motivation for events and creates impact on the reader. It concerns the arrangement of events in a narrated order to cause a determinate affective response from the implied reader. The order duration and frequency of events achieve rhetorical effects. The arrangement of events creates suspension and sometimes surprises when the unexpected occurs.

A typical plot consists of an exposition (setting of the stage); rising of action, often involving conflict between the protagonist and antagonists; the climax of crisis as the point towards the rising action leads; and the conclusion (Anderson 1994:142). The rising of action creates questions in the mind of the implied reader, and the climax and conclusion the answers.

The main plot in Matthew involves God's plan which is challenged by Satan (Powell 1990:47). Matthew introduces
Jesus, the Son of God, as the protagonist whose mission it is to save his people from their sins. His coming provokes a crisis, as characters in the story are confronted with the choice of accepting or rejecting him and his message. According to the evangelist, the proper response is to accept and obey Jesus. The implied reader is challenged to respond as such.

The phases in the Matthean plot can be identified as follows:

- Exposition: At the beginning of the narrative the stage is set. God's plan is clearly stated to save his people from their sins (Mt 1:21). This statement is followed by an elucidation of this introductory statement by way of Jesus' birth narrative (Mt 2), his baptism (Mt 3) and temptation (Mt 4) where his identity, purpose and location in space and time are established. The conflict with the Jewish leaders and the expansion to Gentiles are foreshadowed. Beyond the surface, on a deeper level, conflict with Satan is implicit, as Satan uses the religious leaders to oppose God's plan.

- Rising of action: The action rises with the declaration of the narrator: 'From that time on Jesus began to preach, "Repent, for the kingdom of heaven is near"' (Mt 4:17). Jesus starts his ministry. Suspense is created as groups take various positions as supporters or opponents of Jesus. Jesus calls his disciples (Mt 4:18-22; 9:9) who become his supporters. Interaction between Jesus with his supporters and the various antagonists develops. Conflict between the protagonist and the antagonists forms a central element of the development of the plot. Conflict analysis therefore plays an important role in discovering the Matthean plot (Kingsbury 1988:3). This implies conflict with religious leaders who oppose Jesus' divine authority (Mt 16:1; 19:3; 22:18, 34). The actual conflict is with Satan (Mt 13:36-43; 16:21-23). Suspense is created with frequent anticipation of Jesus' passion (Mt 16:21-28; 17:9-13; 20:17-19).

- Climax: The climax commences with the declaration of the narrator:

From that time on Jesus began to explain to his disciples that he must go to Jerusalem and suffer many things at the hands of the elders, the chief priests and the teachers of the law, and that he must be killed and on the third day be raised to life. (Mt 16:21)

The climax is reached with the ironic victory of Jesus's opponents when the crowds turn against Jesus and he is crucified (Mt 26-27). However, Jesus is resurrected and his opponents devise contrived plans to hide this from the governor (Mt 28:11-15).

- Conclusion: The plot concludes when Jesus meets with his disciples in Galilee and charges them with the Great Commission (Mt 28:16-20).

Within such a developing plot, the implied author (narrator) can use a variety of devices to guide the perception of the implied reader. The description of a plot involves the discovery of elements that connect and interpret the events of the story for the implied reader (Powell 1992:189). 
Anticipation and retrospection are central ordering devices in Matthew's plot. This ranges from vague references to detailed descriptions.

The following serve as examples of devices that the implied author (narrator) uses to prepare the implied readers with anticipation for events to come:

- Supernatural revelations in dreams (Mt 1:20-21; 2:12; 2:13; 2:19-20; 2:22 and 27:19);

- Passion prediction (Mt 16:21; 17:22-23; 20:18-19); and

- Predictions of the resurrection of Jesus (Mt 26:31-32; $28: 5-7 ; 28: 10)$

The implied author (narrator) also makes use of the technique of retrospection. With retrospection the author reviews events that have occurred, e.g.:

- Vague references to the birth story's 'Immanuel, God with us' (Mt 1:23) occur in 'For where two or three gather in my name, there am I with them' (Mt 18:20) and in the Great Commission 'I am with you always' (Mt 28:20).

- Specific reference occurs in the angel's reminder that Jesus had predicted his own resurrection (Mt 28:5-7).

Anticipation and retrospection are also created with repetitions. Judas's betrayal (Mt 26:47-50) is anticipated in Matthew 10:4, 26:14-16 and 20-25. His death (Mt 27:3-10) is anticipated and linked by repetition to Matthew 26:14-15 and 20-25. This death scene is also retrospective of Judas as the one who betrayed Jesus and what happened to the 30 silver coins paid to Judas (Mt 26:15).

The plot of Matthew can also be depicted in terms of a biography (Anderson 1994:144). As biography, it begins with the birth of Jesus (the protagonist), his childhood life, his public ministry, his death, resurrection and, finally, his Great Commission. Throughout this biography, he experiences opposition from King Herod, Satan, the teachers of the Law and the Pharisees as his main antagonists.

The plot can also be depicted in terms of a geographical journey. This journey, broadly speaking, begins in Judea (with the birth of Jesus), proceeds to Egypt (the family's escape from King Herod), then to Galilee (Jesus' public ministry), later to Jerusalem (the death and resurrection of Jesus), and ends in Galilee (with Jesus' Great Commission).

A narrative usually does not have a single plot line, but rather consists of various subplots. A subplot is related by analogy to the main plot, but has its own integrity (Powell 1992:192). It forms an interesting story in its own right. It broadens the reader's perspective on the main plot and enhances its effect (Anderson 1994:172).

The following serves as examples of subplots in Matthew: the life of the disciples, the life of John the Baptist, and the parallels between John and Jesus. John's message, his pronouncements on the Jewish leaders, his arrest and execution foreshadowing the life of Jesus (Mt 3; 11:1-19).
Similarly, the conduct of the religious leaders and the crowds forms subplots. These subplots raise an expectation of the future outcome of the main plot. The subplots provide information and sharpen the implied reader's response.

It must be considered that the task of the author of fiction is different from that of an evangelist (historian). The evangelist did not create characters or events. Various events in the narrative were part of traditions that the evangelist received. Nevertheless, the evangelist had to present these events in a coherent story with beginning, middle and end. This structuring process formed the plot of the Gospel.

\section{Conclusion}

While the grammatico-historical method of Bible interpretation usually diverts from the classical historicalcritical approach, on the one hand, and on the other hand, from reader-response criticism, it is argued that some aspects of the grammatico-historical method overlap with these two approaches. As hermeneutics requires multi-faceted processes, researchers should use methods that fit the requirements of the text investigated. The Gospels are historical narratives, and therefore should be interpreted with methods that are fitting to their literary type. Although recognising its limitations, it is argued that narrative criticism provides useful tools for the interpretation of these kinds of texts. However, this literary paradigm should not be used in such a way as to invalidate the historical and theological aspects of these texts. Narrative criticism allows the reader to focus on the text as coherent narrative. This article used the Matthean Gospel as example to explain this approach.

Jesus forms the main character in this Gospel. Matthew introduces Jesus, the Son of God, as the protagonist whose mission it is to save his people from their sins. The whole plot is orientated towards Jesus, while all characters and incidents are viewed in relation to him. He is surrounded by supporting characters, while he is constantly met by antagonists. Soon after the stage is set, the action rises and suspense is created with a variety of devices. The climax is reached with the ironic victory of Jesus' opponents. However, Jesus is raised from the dead. The plot concludes with the risen Jesus meeting his disciples and charging them with the Great Commission. Throughout the narrative, the narrator provides commentary that is ideologically aligned with Jesus.

The complexity of the communication should be acknowledged. The text provides the encoded version of the author's message which needs to be decoded by the reader. Furthermore, not all detail is told, and the reader needs to fill what is unsaid to create a coherent understanding. Yet, caution must be taken not to let the reader become the arbiter of the meaning of the text. This text limits the range of interpretation of the text.

A narrative critical reading provides a useful tool for the interpretation of the Gospels. 


\section{Acknowledgements Competing interests}

The author declares that he has no financial or personal relationships which may have inappropriately influenced him in writing this article.

\section{References}

Anderson, J.C., 1994, Matthew's narrative web: Over, and over, and over again Sheffield Academic Press, Sheffield.

Beardslee, W.A., 1970, Literary criticism of the New Testament, Fortress, Philadelphia, PA.

Brueggemann, W., 1997, Cadences of home: Preaching among exiles, Westminster John Knox, Louisville, KY.

Burridge, R.A., 1992, What are the Gospels? A comparison with Greco-Roman biography, University Press, Cambridge. (SNTMS 70).

Carson, D.A. \& Moo, D.J., 2005, An introduction to the New Testament, Zondervan, Grand Rapids, MI.

Carter, W., 2000, 'Matthew and the margins: A socio-political reading,' Journal for the Study of the New Testament, suppl.ser. 204.

Culpepper, R.A., 1984, 'Story and history in the Gospels,' Review and Expositor 81, 467-478. https://doi.org/10.1177/003463738408100311

Davies, W.D. \& Allison, D.C., 2004, Matthew 1-7, T\&T Clark, London. (International Critical Commentary, 1).

Domeris, W.R., 1990,“'Blessed are you ...” (Matthew 5:1-12),' Journal of Theology for Southern Africa 73(1), 67-76.

Du Toit, A. (ed.), 2009, Focussing on the message: New Testament hermeneutics, exegesis and methods, Protea, Pretoria.

Edwards, R.A., 1985, Matthew's story of Jesus, Fortress Press, Philadelphia, PA.

Edwards, R.A., 1997, Matthew's narrative portraits of disciples, Trinity Press International, Harrisburg.

France, R.T., 1998, Matthew, evangelist and teacher: New Testament profiles, InterVarsity Press, Westmont, IL.

Fokkelman, J.P., 2000, Reading Biblical narrative: And introductory, John Knox Press, Westminster.

Foster, P., 2004, Community, law and mission in Matthew's Gospel, Mohr Siebeck, Tübingen. (WUNT, 2, Reihe 177).

Gager, J.G., 1975, Kingdom and community: The social world of early Christianity, Prentice-Hall, Englewood Cliffs.

Genette, G., 1980, Narrative discourse: An essay in method, Cornell University, Ithaca, NY.

Gnuse, R., 1990, 'Dream genre in the Matthean infancy narratives', Novum Testamentum 32(2), 97-120. https://doi.org/10.1163/156853690X00016

Greimas, A.J.1983 [1966], Structural semantics: An attempt at a method, transl. D. McDowell, R. Schleifer \& A. Velie, University of Nebraska Press, Lincoln.

Hagner, D.A., 1993, Matthew 1-13, Word Books, Dallas, TX. (Word Biblical commentary, 33A).

Hays, M.H., 2013, 'Towards a faithful criticism', in C.M. Hays \& C.B. Ansbury (eds.) Evangelical faith and the challenge of Historical Criticism, pp 1-23, Baker, Grand Rapids, MI.

Howell, D.B., 1990, 'Matthew's inclusive story: A study in the narrative rhetoric of the first Gospel', Journal for the Study of the New Testament, suppl.ser. 42.

Karris, R.J., 1985, Luke: Artist and theologian, Paulist, New York.

Kennedy, P., 2006, A modern introduction to theology: New questions for old beliefs, I.B. Tauris, London.

Kingsbury, J.D., 1976, 'The title "Son of David" in Matthew's Gospel', Journal for Biblical Literature 95, 591-602. https://doi.org/10.2307/3265574

Kingsbury, J.D., 1988, Matthew as story, Fortress, Philadelphia, PA.
Kingsbury, J.D., 1995, 'The developing conflict between Jesus and the Jewish leaders in Matthew's Gospel: A literary-critical study' in G. Stanton (ed ). The interpretation of Matthew, pp. 179-197, T\&T Clark, Edinburgh.

Klijn, A.F.J., 1968, De wordingsgeschiedenis van het Nieuwe Testament, Het Spectrum NV, Utrecht

Lategan, B.C., 1982, 'Structure and reference in Mt 23', Neotestamentica 16, 74-87.

Love, S.L., 2009, Jesus and marginal women: The Gospel of Matthew in social-scientific perspective, James Clarke \& Co., Cambridge.

Luz, U., 1990, Matthew 1-7, a commentary, T\&T Clark, Edinburgh.

Luz, U., 2005, Studies in Matthew, Eerdmans, Grand Rapids, MI.

Malina, B.J. \& Rohrbauch, R.L., 2003, Social-science commentary on the Synoptic Gospels, Fortress Press, Minneapolis, MN.

Matera, F., 1987, 'The plot of Matthew's Gospel', Catholic Biblical Quarterly 49, 233-253.

Mohrlang, R., 1984, Matthew and Paul: A comparison of ethical perspectives, Cambridge University Press, Cambridge.

Overman, J.A., 1996, Church and community in crisis: The Gospel according to Matthew, Trinity Press International, Harrisburg.

Pennington, J.T., 2012, Reading the Gospels wisely: A narrative and theological introduction, Baker Academic, Grand Rapids, MI.

Perrin, N., 1972, 'The evangelist as author: Reflections on method in study and interpretation of Synoptic Gospels and Acts', Biblical Research 17, 5-18.

Powell, M.A., 1990, What is narrative criticism?, Fortress Press, Minneapolis, MN.

Powell, M.A., 1992, 'The plot and subplots of Matthew's Gospel', New Testament Studies 38, 187-204. https://doi.org/10.1017/S0028688500019858

Prince, G., 2003, A dictionary of narratology, University of Nebraska Press, Nebraska. Rigaux, B., 1968, The testimony of St. Matthew, Franciscan Herald Press, Chicago, IL.

Saldarini, A.J., 1994, Matthew's Christian-Jewish Community, University of Chicago, Chicago, IL.

Senior, D., 1998, Matthew, Abingdon, Nashville, TN.

Stanton, G.N., 1992, 'The communities of Matthew', Interpretation 46(4), 379-391.

Theissen, G., 1993, Social reality and the early Christians, T\&T Clark, Edinburgh.

Tolmie, D.F., 1999, Narratology and Biblical narratives: a practical guide, Wipf\&Stock, Eugene, OR.

Turner, D.L., 2008, Matthew, Baker Academic, Grand Rapids MI.

Van Aarde, A., 2009, 'Narrative criticis", in A. du Toit (ed.), Focussing on the message. New Testament hermeneutics, exegesis and methods, pp.381-417, Protea, Pretoria

Van Aarde, A., 2011, "'On earth as is in heaven" - Matthew's eschatology as the Kingdom of Heavens that has come', in J.G. van der Watt (ed.), Eschatology of the New Testament and some related documents, pp. 35-63, Mohr Siebeck, Tübingen. (WUNT 2, 315).

Versteeg, J., 1992, Evangelie in viervoud: Eenkarakteristiek van de vierevangeliën, Kok, Kampen.

Viljoen, F.P., 2007, 'Fulfilment in Matthew', Verbum et Ecclesia 28(1), 301-324. https:// doi.org/10.4102/ve.v28i1.109

Viljoen, F.P., 2009, 'Matthew's portrait of Jesus', Nederduits Gereformeerde Teologiese Tydskrif 50(1\&2), 269-279.

Viljoen, F.P., 2014a, 'Hosea 6:6 and identity formation in Matthew', Acta Theologica 34(1), 214-237. https://doi.org/10.4314/actat.v34i1.12

Viljoen, F.P., 2014b, 'Jesus healing a leper and the purity law in Matthew', In Luce Verb 48(2), Art. \#1751, 7 pages. http://dx.doi.org/10.4102/ids.v48i2.1751.

Viljoen, F.P., 2018, 'The Matthean Jesus' surprising instruction to obey the teachers of the Law and Pharisees', HTS Theological Studies 74(1). https://doi.org/10.4102/ hts.v74i1.4911

Weaver, D.J., 1996, 'Power and powerlessness: Matthew's use of irony in the portrayal of political leaders,' in D.R. Bauer \& M.A. Powell (eds.), Treasures new and old: Contributions to Matthean studies, pp. 179-196, Scholars Press, Atlanta, GA.

Weren, W.J.C., 1994, Belichting van het Bijbelboek; Matteüs, Katholieke Bijbelstichting, 's-Hertogenbosch.

Weren, W.J.C., 2014, Studies in Matthew's Gospel, literary design, intertextuality, and social setting, Brill, Leiden. 